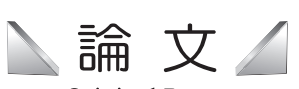

Original Paper

\section{製紙スラッジ焼却灰造粒材料を用いたモルタルの プレキャスト材料としての性能評価 *}

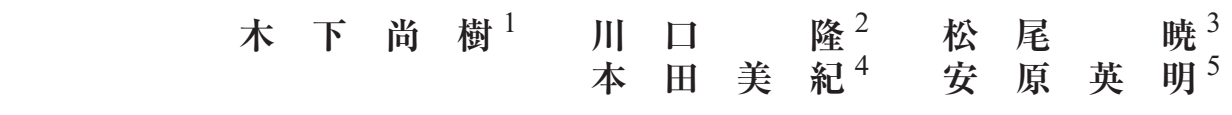

\title{
Evaluation of Performance of Mortar Using Granulated Paper Sludge Ash for Precast Material
}

\author{
by Naoki KINOSHITA ${ }^{\mathrm{a}}$, Takashi KAWAGUCHI ${ }^{\mathrm{b}}$, Takashi MATSUO ${ }^{\mathrm{c}}$, \\ Miki HONDA $^{\mathrm{d}}$ and Hideaki YASUHARA ${ }^{\mathrm{e}}$
}
a. Assistant Professor, Graduate School of Science and Engineering, Ehime University, 3 Bunkyo-Cho, Matsuyama 790-8577 Japan
(Corresponding author, E-mail: kino@cee.ehime-u.ac.jp, TEL\&FAX: 089-927-9823)
b. Technical Staff, Faculty of Engineering, Ehime University
c. Chief engineer, Yosyu Kogyo Co., Ltd.
d. Graduate student, Graduate School of Science and Engineering, Ehime University
e. Associate Professor, Graduate School of Science and Engineering, Ehime University

\begin{abstract}
The paper sludge which is generated during paper manufacturing processes is incinerated to reduce its volume, and then the paper sludge ash is produced. The greater part of the paper sludge ash has been disposed to landfills and an effective utilization of the paper sludge ash has not been promoted. From view point of the effective utilization of industrial wastes, the authors have proposed that the granulated materials made of the paper sludge ash are used for concrete aggregate and evaluated the applicability of paper sludge ash to concrete. The concrete using the granulated paper sludge ash is lighter, and its water absorption is much higher than those of ordinary concretes. The drying shrinkage strain is larger than that of ordinary concretes.

The lightweight precast materials used for such as forms have a merit of the cost reduction of transportation and construction. In this study, the applicability of the mortar using granulated paper sludge ash for aggregate (PS mortar) to precast lining form is examined. Firstly, the flowability and the strength of the PS mortar are examined and the curing performance of the PS mortar form is indirectly evaluated by measuring strength and air tightness of back filling concrete. Secondly, the drying shrinkage of the PS mortar is measured and its prediction equation is proposed. Finally, Practicality of the PS mortar to precast materials is evaluated by observing deformation and crack occurring of the precast PS mortar walls constructed tentatively in this study. From results of the above examinations, it is found that the PS mortar form has a high curing performance. However, the PS mortar may not be unconditionally utilized because its drying shrinkage strain is relatively large.
\end{abstract}

KEY WORDS: Paper Sludge Ash, Granulated Aggregate, Mortar, Drying Shrinkage, Precast

\section{1. は じめに}

製紙排水の処理工程から発生する製紙スラッジは，一部は再資 源化されるが，大半は焼却されて製紙スラッジ焼却灰 (PS 灰) と なる。PS 灰は産業廃棄物で, 一部はセメント原料などに利用さ れるが, 大半は埋め立て処分されており, 有効利用が進んでいる

*2012 年 5 月 1 日受付 2012 年 7 月 31 日受理

1. 正会員 愛媛大学大学院 理工学研究科助教

2. 愛媛大学工学部技術専門職員

3. 株式会社予州興業環境部 主任

4. 愛媛大学大学院 理工学研究科 大学院生

5. 正会員 愛媛大学大学院 理工学研究科准教授

[ 著者連絡先 ] TEL\&FAX: 089-927-9823 (愛媛大・木下) E-mail:kino@cee.ehime-u.ac.jp

キーワード: 製紙スラッジ焼却灰, 造粒骨材, モルタル, 乾燥収縮, プレ キャスト
とは言い難い ${ }^{1)}$ 。筆者らはPS 灰をフライアッシュと混合し，セ メントを添加して造粒固化した材料をコンクリート用骨材に利用 することを提案し, PS 灰造粒材料のコンクリート用骨材として の性状やそれを用いたコンクリートの硬化後の強度特性, 耐久性 などについて評価した。これまでの検討により細骨材にPS 灰造 粒骨材を使用した場合でも, 配合により鉄筋コンクリート構造物 使用基準強度の $30 \mathrm{~N} / \mathrm{mm}^{2}$ を満たすことが可能であるが，PS 造 粒骨材の強度が通常の骨材の強度より小さいことからコンクリー トとした場合の強度が小さくなる。また, $2000 \mathrm{~kg} / \mathrm{m}^{3}$ 程度の軽量 なコンクリートとなることや, 高吸水性があり, 乾燥収縮量が大 きく, 凍結融解試験による評価では耐凍害性は高いことなどがわ かっている ${ }^{2,3)}$ 。特に, 乾燥収縮については通常の骨材を用いた コンクリートの $1.4 〜 1.7$ 倍収縮することがわかっている ${ }^{3)}$ 。以 上のような結果から, コンクリート用骨材としての適用範囲は通 
木下尚樹・川口 隆・松尾 暁・本田美紀・安原英明

Table 1 Composition of oxides in paper sludge ash and fly ash.

\begin{tabular}{crrr}
\hline Oxide & $\begin{array}{c}\text { Paper sludge } \\
\text { ash }\end{array}$ & Fly ash & $\begin{array}{c}\text { Ordinary portland } \\
\text { cement }\end{array}$ \\
\hline $\mathrm{SiO}_{2}$ & 34.2 & 69.9 & 21.9 \\
$\mathrm{Al}_{2} \mathrm{O}_{3}$ & 22.8 & 14.4 & 5.2 \\
$\mathrm{Fe}_{2} \mathrm{O}_{3}$ & 1.4 & 2.5 & 3.0 \\
$\mathrm{CaO}$ & 32.4 & 0.9 & 63.9 \\
$\mathrm{MgO}$ & 3.2 & 0.8 & 1.6 \\
$\mathrm{SO}_{3}$ & 1.4 & 0.2 & 2.0 \\
Unburned carbon & 4.0 & 7.1 & - \\
\hline & & & unit: wt. \%
\end{tabular}

常の骨材と比べて極めて限定的であり, 構造用部材への使用は現 状では困難であると考えられる。

既往の研究においてコンクリートやモルタルの乾燥収縮に関し ては多く検討されている。例えば, Kayali ら ${ }^{4)}$ は䋊維補強された軽 量骨材を用いた繊維補強コンクリートの乾燥収縮について, 骨材 と繊維の影響を検討している。また, 今本ら ${ }^{5)}$ は骨材の比表面積 とコンクリートの乾燥収縮には高い相関性があることを指摘して いる。乾燥収縮は, 耐久性能低下の要因の 1 つであるひび割れの 発生原因であるため, 収縮挙動の把握, 対策が必要である。その ため, 土木学会式 ${ }^{6)}$, 建築学会式 ${ }^{7)}$, Gardner 式 ${ }^{8)}$, Bazant 式 ${ }^{9)}$, 複合モデル式 ${ }^{10)}$ などコンクリートの乾燥収縮予測式が数多く提案 されている。これら既往の研究から, 乾燥収縮はPS 灰造粒骨材 のモルタルへの適用性評価で重要な影響因子の一つといえる。

型枠などのプレキャスト材は軽量である程，運搬コストの削減 となるメリットがある。また, 型枠に使用する材料が高い吸水性 を有していれば, 弱材齢時のコンクリートに対する養生効果が期 待され, 保護を必要とするコンクリート構造物の密実性が高めら れるものと期待される。そこで本研究では, PS 灰の高吸水性や 軽量な特徴に着目し, プレキャスト埋設型モルタル製型枠への PS 灰造粒骨材を用いたモルタルの適用性について検討する。具 体的には, まず, モルタルの流動性, 強度および型枠として使用 した際の内部コンクリートへの養生効果について評価する。つぎ に, 乾燥収縮試験を実施し, モルタルの乾燥収縮挙動の評価, 乾 燥収縮挙動を再現できる予測式の提案を行い, それらを評価する。 さらに, PS モルタルの実用性について検討するために, プレキャ ス卜塀板を試験施工し，経過観察により評価する。

\section{PS 灰造粒骨材の性状}

\section{$2 \cdot 1$ 造粒骨材の製造}

PS 灰造粒骨材は, PS 灰, 石炭灰および添加材の高炉セメント $\mathrm{B}$ 種，石灰を原料とし，練混ぜ水を加えて製造する。本研究では 愛媛県四国中央市にある製紙工場から中間処理プラントが処理の ため受け入れた PS 灰および石炭灰を使用する。Table 1 に PS 灰, 石炭灰および普通ポルトランドセメントの化学組成を示す。PS 灰の主成分は $\mathrm{SiO}_{2}, \mathrm{Al}_{2} \mathrm{O}_{3}$ および $\mathrm{CaO}$ で, 主成分は石炭灰およ びセメントと同様である。また, PS 灰には未燃カーボンが含有 している。造粒には日本アイリッヒ社製逆流式混合機 DEV29 用いる。有効容量は $4000 \mathrm{~L}$ である。本研究では 1 バッチ当たり $2 \mathrm{~m}^{3}$ で時間当たり約 $10 \mathrm{~m}^{3}$ で造粒骨材を製造する。主材, 添加 材および練り混ぜ水をミキサー内に投入後, 攪汼して造粒する。

Table 2 にPS 死造粒骨材の配合を示す。PS 灰 : 石炭灰が質量 比で $2.5: 1$, セメント量, 水量および石灰の配合量はPS 灰およ び石炭灰の総質量に対してそれぞれ $7 \%, 43.8 \%, 3 \%$ とする。 造粒した骨材の養生は屋根付きヤード内に 1 日放置後, $25^{\circ} \mathrm{C}$ に 保たれた室内にて自然乾燥 (dry) する。点載荷試験の結果から圧 縮強さを推定 ${ }^{11)}$ すると, 約 $16 \mathrm{~N} / \mathrm{mm}^{2}$ である。
Table 2 Mixture proportion of granulated aggregate.

\begin{tabular}{cccccc}
\hline \multirow{2}{*}{$\begin{array}{c}\text { Mixture ratio } \\
\text { PS/FA }\end{array}$} & PS & FA & BB & Water & Lime \\
\cline { 2 - 6 } & 1000 & 400 & $98(7)$ & $613(43.8)$ & $42(3)$ \\
\hline 2.5 & &
\end{tabular}

PS: Paper sludge ash, FA: Fly ash, BB: Portland blast-furnace slag cement B

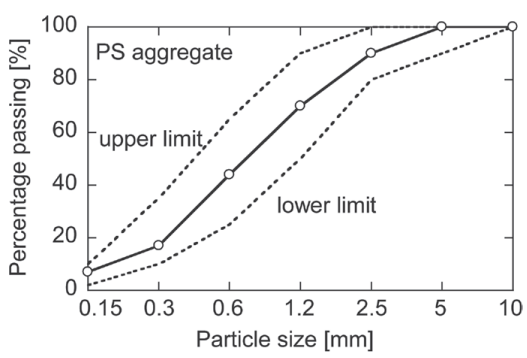

Fig.1 Particle size distribution curve of granulated PS fine aggregate.

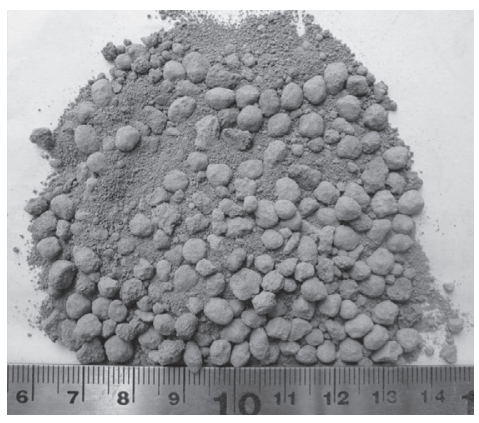

Fig.2 Resulting granulated fine aggregate using paper sludge ash.

\section{$2 \cdot 2$ 細骨材としての性状}

Fig. 1 に細骨材として使用する PS 灰造粒骨材の粒度曲線を示 す。粒度の標準範囲である上限值と下限值を破線で示している。

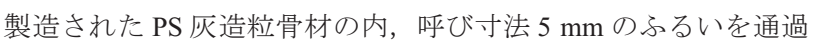
したものを使用寸る。Fig. 2 に造粒製造され， $5 \mathrm{~mm}$ 以下にふるい わけされた PS 灰造粒骨材を示す。さらに, 粒度が標準範囲内に 入るように, 分級した $5.0 \mathrm{~mm}$ 以下の骨材を質量比で $1.2 \mathrm{~mm}$ 以上:

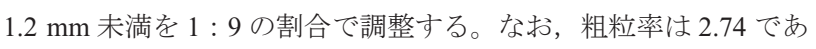
る。JIS A 1134 構造用軽量骨材の密度および吸水率試験方法によっ て求めた密度および吸水率は $1.65 \mathrm{~g} / \mathrm{cm}^{3}$ および $48.6 \%$ で, 海砂お よび砕砂の表乾密度はそれぞれ $2.55 \mathrm{~g} / \mathrm{cm}^{3}, 2.54 \mathrm{~g} / \mathrm{cm}^{3}$, 吸水率は $2.2 \sim 2.4 \%$ であることから, PS 灰造粒骨材は天然の骨材と比較し, 軽量で極めて高い吸水性能を持っている。JIS A 1104 に従って求 めた PS 灰造骨材の単位容積質量は $0.86 \mathrm{~kg} / \mathrm{L}$, 実績率は $50.3 \%$ で, 単位容積質量は砕砂の約半分で, 実績率も約 $10 \%$ 低い。

\section{PS 灰造粒骨材を用いたモルタルのプレキャスト型枠への適用性}

\section{$3 \cdot 1$ 実験方法および使用材料}

PS モルタルを作製するにあたり，平板状の型枠として使用す る際に必要な曲げ耐力を向上させるために繊維を用いることを検 討する。混入を検討する補強䋊維は, ビニロン繊維, ポリプロピ レン繊維および廃ペットボトルから製造された緎維 (PET 繊維) である。Fig. 3 に各繊維の外観を, Table 3 に物理的性質をに示す。 一般的に用いられている鋼絨維は密度が高いことから PS モルタ ルに混入した際に単位質量が増加し, 軽量な PS 灰造粒骨材の特 徵を生かすことができないと判断し検討の対象外とする。また， 近年繊維素材として有用とされている炭素繊維は高価であること から経済性に欠けるため対象外とする。

繊維を混入して試し練りを行ない, ワーカビリティおよび繊維 

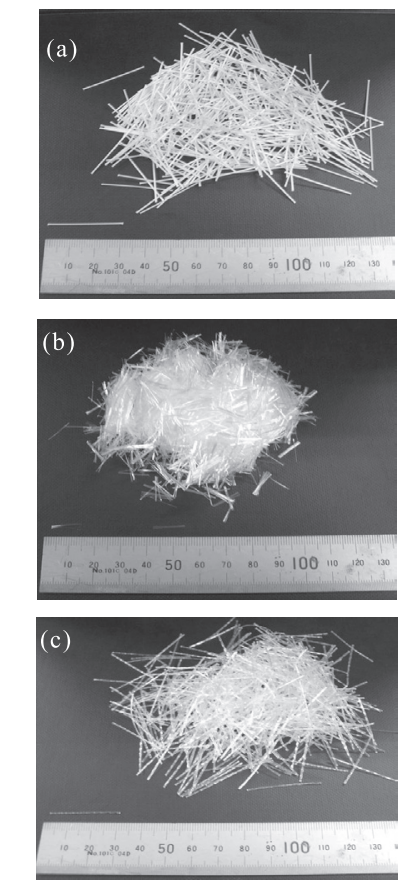

Fig.3 Fibers pre-mixed within PS mortar. (a): vinyl resin. (b): PP. (c): PET.

Table 3 Physical properties of fiber pre-mixed within PS mortar.

\begin{tabular}{lrrrrr}
\hline Fiber & $\begin{array}{c}\text { Diameter } \\
{[\mu \mathrm{m}]}\end{array}$ & $\begin{array}{c}\text { Length } \\
{[\mathrm{mm}]}\end{array}$ & $\begin{array}{c}\text { Tensile strength } \\
{\left[\mathrm{N} / \mathrm{mm}^{2}\right]}\end{array}$ & $\begin{array}{c}\text { Young's modulus } \\
{\left[\mathrm{kN} / \mathrm{mm}^{2}\right]}\end{array}$ & $\begin{array}{r}\text { Density } \\
{\left[\mathrm{g} / \mathrm{cm}^{3}\right]}\end{array}$ \\
\hline Vinyl resin & 660 & 30 & 861 & 23.0 & 1.30 \\
PP & 43 & 12 & 500 & 7.5 & 0.91 \\
PET & 700 & 30 & 450 & 20.0 & 1.32 \\
\hline
\end{tabular}

Table 4 Mixture proportions of mortar using granulated PS fine aggregate.

\begin{tabular}{lcccccccr}
\hline \multirow{2}{*}{ Fiber } & \multirow{2}{*}{$\begin{array}{c}\text { W/C } \\
\text { [\%] }\end{array}$} & $\begin{array}{c}\text { PS/V } \\
{[\%]}\end{array}$ & W & C & S & G & AE-WR & Fiber \\
\hline Non-fiber & 30 & 37 & 296 & 1021 & 607 & 0 & 10.2 & 0.00 \\
Vinyl resin & 30 & 37 & 290 & 1000 & 595 & 0 & 10.0 & 25.49 \\
PP & 30 & 37 & 295 & 1017 & 605 & 0 & 10.2 & 1.82 \\
PET & 30 & 37 & 290 & 1000 & 595 & 0 & 10.0 & 25.88 \\
\hline
\end{tabular}

$\mathrm{PS} / \mathrm{V}$ : Percentage of PS to fine aggregate by mortar volume

Table 5 Physical properties of mortar using granulated PS fine aggregate.

\begin{tabular}{lrrr}
\hline \multicolumn{1}{c}{ Fiber } & $\begin{array}{c}\text { Flow } \\
{[\mathrm{mm}]}\end{array}$ & $\begin{array}{r}\text { Compressive strength } \\
{\left[\mathrm{N} / \mathrm{mm}^{2}\right]}\end{array}$ & $\begin{array}{r}\text { Bending strength } \\
{\left[\mathrm{N} / \mathrm{mm}^{2}\right]}\end{array}$ \\
\hline Non-fiber & 221 & 46.4 & 5.9 \\
Vinyl resin & 171 & 53.4 & 8.4 \\
PP & 198 & 54.1 & 8.0 \\
PET & 219 & 48.9 & 7.3 \\
\hline
\end{tabular}

の分散性を考慮し, 流動性の指標であるモルタルフロー值の目標 值を $180 \mathrm{~mm} \sim 200 \mathrm{~mm}$ と設定する。配合条件として, PS 灰造粒 骨材の使用により強度が低下することを考慮し, 水セメント比を $30 \%$ と設定する。さらに低水セメント比による流動性の不良を 改善するため, 高性能 $\mathrm{AE}$ 減水剂を使用する。練り混ぜ時間はセ メント，水および高性能 $\mathrm{AE}$ 減水剂によるセメントペーストでの 練り混ぜを 1 分間, PS 灰造粒骨材を投入したモルタルでの練り 混ぜを 1 分間, さらに繊維を混入し 1 分間練り混ぜて合計 3 分間 とする。䋊維を混入しない場合はPS 灰造粒骨材を混入し, 2 分 間練り混ぜる。養生は, 温度 $20 \pm 2{ }^{\circ} \mathrm{C}$ の水中で 28 日間とする。 その後, セメントの物理試験方法 (JIS R 5201) に準じて圧縮強さ 試験および曲げ強さ試験を行う。供試体寸法は $40 \mathrm{~mm} \times 40 \mathrm{~mm} \times$ $160 \mathrm{~mm}$ の角柱供試体である。一般に供用されている型枠には曲 げ強さの規定がないため, 現在実用されている型枠の曲げ強さを 参考にして, 曲げ強さの目標值を $8.0 \mathrm{~N} / \mathrm{mm}^{2}$ 以上とする。

\section{$3 \cdot 2$ 流動性および強度}

Table 4 に繊維の違いによる流動性および強度を評価するため のモルタルの配合を示す。全体積に占める PS 灰造粒骨材の体積 割合は $37 \%$ とする。さらに高性能 $\mathrm{AE}$ 減水剂添加量は, 効果を 同一とするためいずれの場合もセメント質量の $1.0 \%$ とする。各 繊維の混入率は, ビニロン繊維および PET 繊維は容積比で全体積 の $2.0 \%$, ポリプロピレン繊維は $0.20 \%$ とする。Table 5 にモル タルフロー值, 圧縮強さおよび曲げ強さを示す。フレッシュモル タルの流動性に関して, フロー值は繊維を混入しなかった場合に 対して, ビニロン繊維, ポリプロピレン繊維を混入した場合は減 少する。一方で PET 繊維を混入した場合は減少せず, 目標值で ある $180 \mathrm{~mm} \sim 200 \mathrm{~mm}$ を満たしているのはポリプロピレン繊維 と PET 繊維である。繊維に混入により圧縮強さ, 曲げ強さは増加 する傾向にあるが, PET 䋊維の曲げ強さの補強効果は他の䋊維と 比較し小さい。曲げ強さの目標值として設定している $8.0 \mathrm{~N} / \mathrm{mm}^{2}$ に達しているのはビニロン繊維, ポリプロピレン繊維を混入した 場合である。なお，硬化後の PS モルタル供試体の吸水率は $25 \%$ と高い值を示した。

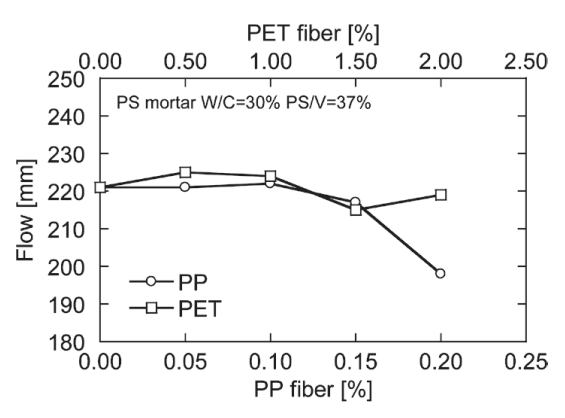

Fig.4 Relationship between flow of PS mortar and fiber mixture ratio.

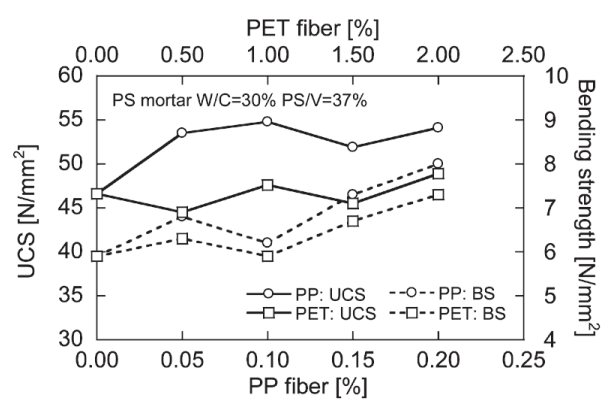

Fig.5 Relationship between strength of PS mortar and fiber mixture ratio.

つぎに繊維の混入率を変化させることにより, フレッシュモル タルの流動性, 圧縮強さ, 曲げ強さへの影響を確認する。繊維は ポリプロピレン繊維, PET 繊維を使用し, 混入率はポリプロピレ ン䋊維では $0.0 \sim 0.20 \%$, PET 䋊維では $0.0 〜 2.0 \%$ でそれぞれ 5 段階とする。Fig. 4 にフロー試験の結果を示す。ポリプロピレ ン繊維では, 繊維混入率が $0.15 \%$ 以上でフロー值が減少してい る。PET 繊維では, 繊維混入により減少傾向はみられるがその值 はポリプロピレン繊維と比較して小さい。PET 繊維において流動 性の低下が小さいのは, 繊維の表面形状が滑らかであり, 他の繊 維と比べてモルタルとの界面での摩擦が小さかったものと考えら れる。Fig. 5 に強度試験の結果を示す。いずれの繊維においても 


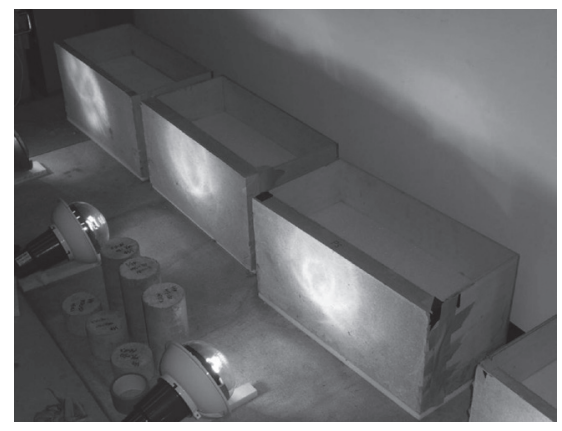

Fig.6 Condition of concrete curing for PS mortar form.

混入率の増加に伴い圧縮強さ, 曲げ強さとも増加している。PET 繊維では圧縮強さの変化は小さい。本実験では混入率の上限を, ポリプロピレン繊維では $0.20 \%$, PET 繊維では $2.0 \%$ としたが, 混入率を上げても強度が増加する傾向にあると考えられ, 経済性 を考慮しながら混入率の上限值を見極める必要がある。

\section{$3 \cdot 3$ プレキャスト型枠としての養生効果}

PS モルタルで作製した平板を型枠としてコンクリートを打設, 養生後, コンクリートの強度および密実性を評価することにより, プレキャスト型枠としての養生効果を確認する。PS モルタル平 板の寸法は, $600 \mathrm{~mm} \times 300 \mathrm{~mm}$ とし, 厚さは $50 \mathrm{~mm}$ および $30 \mathrm{~mm}$ の 2 種類とする。また, 比較として砕砂を用いたモルタル ( 普通 モルタル）型枠も作製する。配合は，水セメント比は $30 \%$, 細 骨材の混入割合は容積比で全体積の $37 \%$ として, 混入する繊維 はポリプロピレン繊維とし全体積に対して $0.2 \%$ 使用し（Table 4 参照), 標準養生で材齢は 28 日と寸る。作製した平板の普通モ ルタルの単位体積質量は $2090 \mathrm{~kg} / \mathrm{m}^{3}$ であったが, それに対して PS モルタルは $1710 \mathrm{~kg} / \mathrm{m}^{3}$ であり, 約 $20 \%$ 軽量化を図ることが できている。また, 吸水率は普通モルタルが $7.4 \%$, PS モルタル が $25 \%$ ，であることから PS モルタルは約 3.4 倍の吸水性能を有 している。養生効果を確認するコンクリートの寸法は $600 \mathrm{~mm} \times$ $300 \mathrm{~mm} \times 300 \mathrm{~mm}$ とし, 型枠として $600 \mathrm{~mm} \times 300 \mathrm{~mm}$ の側面 1 面 にモルタル平板を使用し，他の側面には木製合板を使用する。底 面には鋼製型枠を使用する。ただしPS モルタル型枠は28 日の 標準養生後, 約 1 週間で型枠として組み立て内部コンクリートを 打設しており，その間は自然乾燥状態となっている。打設するコ ンクリートの配合は, 水セメント比を $50 \%$, 細骨材率を $47 \%$ と する。 $20 \pm 2{ }^{\circ} \mathrm{C}$ の恒温室内において打設後 1 日は室内で上面に断 熱材等を施し水分の逸散を防ぐ。2 日目に底面の鋼製型枠を断熱 材に置き換える。また, Fig. 6 に示すようにPS モルタルの吸水 性および保水性の効果をより明らかにするため側面のモルタル平 板が設置されている面に対して直射日光を想定して $50 \mathrm{~cm}$ の距離 から $500 \mathrm{~W}$ の屋外用ライトで照射する。さらに, モルタル平板 の厚さが $30 \mathrm{~mm}$ の型枠に対しては 1 日 1 回霧吹きによって型枠 表面が十分濡れる程度水分を供給した。また, 打設と同時にコン クリートの円柱供試体 $(\phi 100 \mathrm{~mm} \times 200 \mathrm{~mm})$ を作製し, 標準養生 する。すべての養生期間は 28 日とする。

PS モルタルのプレキャスト型枠としての養生効果を確認するた め, 型枠内部に打設されたコンクリートの強度および密実性を評 価する。ここでは一軸圧縮試験と透気試験を行う。供試体を作製 するにあたり, Fig. 7 に示すように養生後のコンクリートの可能な 限りモルタル平板に近い場所 ( コンクリート側面とコア側面の間 隔は約 $30 \mathrm{~mm}$ ) からコアを採取し, 一軸圧縮試験用には $\phi 50 \mathrm{~mm} \times$ $100 \mathrm{~mm}$ ，透気試験用には $\phi 100 \mathrm{~mm} \times 50 \mathrm{~mm}$ の供試体を作製する。 透気試験で求まる透気係数はコンクリートの緻密さの程度を表す

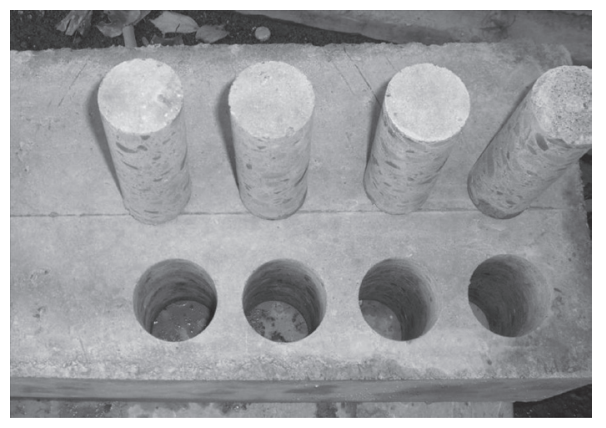

Fig.7 Condition of core sampling.

Table 6 Compressive strength and coefficient of air permeability of concrete using PS mortar form.

\begin{tabular}{|c|c|c|c|}
\hline \multicolumn{2}{|c|}{ Form type } & \multirow{2}{*}{$\begin{array}{c}\text { Compressive } \\
\text { strength } \\
{\left[\mathrm{N} / \mathrm{mm}^{2}\right]}\end{array}$} & \multirow{2}{*}{$\begin{array}{l}\text { Coefficient of } \\
\text { air permeability } \\
{\left[\times 10^{-5} \mathrm{~cm}^{4} \mathrm{~N}^{-1} \mathrm{~s}^{-1}\right]}\end{array}$} \\
\hline $\begin{array}{c}\text { Fine } \\
\text { aggregate }\end{array}$ & $\begin{array}{c}\text { Thickness } \\
{[\mathrm{mm}]}\end{array}$ & & \\
\hline PS & 30 & 41.7 & 2.71 \\
\hline PS & 50 & 41.9 & 2.67 \\
\hline Sand & 30 & 28.6 & 4.93 \\
\hline Sand & 50 & 35.2 & 3.34 \\
\hline \multicolumn{2}{|c|}{ Cylinder sample } & 51.5 & 1.19 \\
\hline
\end{tabular}

気密性の性能照査を行うための指標である。供試体を養生後に透 気面 $(\phi 100 \mathrm{~mm})$ 以外の 4 側面をエポキシ樹脂系接着剤で気密処理 し, 透気面の両面に空気により $0.2 \mathrm{MPa}\left(20 \mathrm{~N} / \mathrm{cm}^{2}\right)$ の差圧をかけ, 2 時間に供試体を透過した空気量を測定する。透気係数 $\mathrm{K}$ はダル シー則より導出される次式によって算出する ${ }^{12)}$ 。

$$
K=\frac{2 L P_{2}}{P_{1}^{2}-P_{2}^{2}} \frac{Q}{A}
$$

ここで, $K:$ 透気係数 $\left[\mathrm{cm}^{4} /(\mathrm{N} \cdot \mathrm{s})\right], L:$ 供試体厚さ $[\mathrm{cm}], P_{1}$ : 流入側圧力 $\left[\mathrm{N} / \mathrm{cm}^{2}\right], P_{2}$ : 流出側圧力 $\left[\mathrm{N} / \mathrm{cm}^{2}\right], Q:$ 透気量 $\left[\mathrm{cm}^{3} / \mathrm{s}\right]$, $A:$ 透気面積 $\left[\mathrm{cm}^{2}\right]$ である。

Table 6 に圧縮強さおよび透気係数を示す。標準養生された円 柱供試体は十分水和反応し, 強度が最大限発現しているものと考 えると, PS モルタル型枠を使用したコンクリートは約 $80 \%$, 普 通モルタルは $55 \sim 70 \%$ の強度発現である。PS モルタルは普通 モルタルの場合と比較し $1.2 \sim 1.4$ 倍の強度である。これは, PS モルタルの高い吸水性能に起因し, PS モルタルから水和反応に 必要な水の供給が行われ, 強度発現が促されていると考えられる。 また, PS モルタルの場合, 厚さ $30 \mathrm{~mm}$ でも表面に水の供給があ れば，厚さ $50 \mathrm{~mm}$ と同程度の効果があることがわかる。一方で, 普通モルタルの場合, 厚さ $30 \mathrm{~mm}$ では水の供給があっても表面 照射の影響で, 型枠表面が乾燥し内部コンクリートまでは水分が 供給されず強度発現につながらないことがわかる。厚さ $50 \mathrm{~mm}$ の場合は照射の影響は内部コンクリートまでは影響していないこ とがわかる。透気係数も強度と調和的な結果となっている。

普通モルタルに対してPS モルタルは単位体積質量が小さく軽 量であること, また, 普通モルタル平板を用いて養生したコンク リートに対して, PS モルタル平板を型枠として用いて養生したコ ンクリートは強度, 密実性が高く, PS 灰造粒骨材を細骨材として 用いた型枠の有効性が確認された。しかし, 内部コンクリートへ の水および熱の供給状況の検討は不十分であり, 十分な因果関係 は検証できなかった。また, 標準養生を行った円柱供試体のコン クリートに対して, PS モルタル板を用いて養生したコンクリート は強度, 密実性が劣っており, これらの向上が課題と考えられる。 
Table 7 Mixture proportions of mortar used for measuring drying shrinkage.

\begin{tabular}{lrrrrrr}
\hline & & \multicolumn{5}{c}{$\left[\mathrm{kg} / \mathrm{m}^{3}\right]$} \\
\cline { 4 - 7 } Type & $\begin{array}{c}\text { W/C } \\
{[\%]}\end{array}$ & $\begin{array}{c}\text { PS/V } \\
{[\%]}\end{array}$ & W & C & S & Fiber \\
\hline i & 40 & 44 & 279 & 698 & 721 & - \\
ii & 40 & 30 & 357 & 893 & 492 & - \\
iii & 40 & 60 & 190 & 474 & 721 & - \\
iv & 40 & 44 & 279 & 698 & 721 & 4.6 \\
\hline
\end{tabular}

Table 8 Specimen's names and conditions of drying shrinkage tests.

\begin{tabular}{lccrrr}
\hline \multicolumn{1}{c}{ Specimen } & $\begin{array}{c}\text { PS/V } \\
{[\%]}\end{array}$ & $\begin{array}{c}\text { Mixture } \\
\text { proportion }\end{array}$ & $\begin{array}{r}\text { Volume/Surface } \\
{[\mathrm{mm}]}\end{array}$ & Fiber & $\begin{array}{r}\text { Number of } \\
\text { specimens }\end{array}$ \\
\hline PS44-25-1 & 44 & i & 25 & - & 3 \\
PS44-50 & 44 & i & 50 & - & 3 \\
PS44-100 & 44 & i & 100 & - & 3 \\
PS44-25-2 & 44 & i & 25 & - & 3 \\
PS30-25 & 30 & ii & 25 & - & 3 \\
PS60-25 & 60 & iii & 25 & - & 3 \\
PS44-25F & 44 & iv & 25 & PP & 3 \\
\hline
\end{tabular}

PS/V: Percentage of PS to fine aggregate by mortar volume Mixture proportion: Refer to Table 7

\section{PS 灰造粒骨材を用いたモルタルの乾燥収縮}

\section{$4 \cdot 1$ 実験方法}

PS 灰造粒骨材を用いたコンクリートの乾燥収縮ひずみは，一般 的なコンクリートの約 $1.4 〜 1.7$ 倍大きいことがわかっている ${ }^{3)}$ 。 原因として，乾燥収縮量が大きいセメントペーストの量が多い, PS 灰造粒砂自身の収縮が大きいことが考えられ，コンクリート の乾燥収縮量については用途により上限值が規定されている場合 もあり ${ }^{13)}$ ，PS モルタルでの検討も必要である。ここでは乾燥収 縮の影響因子としてPS 灰造粒骨材の割合, 体積表面積比, 繊維 混入の有無を想定し，乾燥収縮試験によって検討する。

Table 7 に配合を示す。水セメント比を $40 \%$ とし, 細骨材割 合が乾燥収縮に及ぼす影響を検討するため, 質量比を W : C : $\mathrm{S}=1: 2.5: 4$ とする。全体積に占める PS 灰造粒骨材の体積割合（細 骨材割合）の基準值を $44 \%$ に定め, 約 $\pm 15 \%$ 変化させ， $30 \%$, $44 \%$ ，60\%の 3 種類を設定する。細骨材割合 $44 \%$ の配合におい ては, 繊維混入の有無が乾燥収縮に及ぼす影響を検討するため, 混和材にポリプロピレン繊維 (PP繊維) を全体積の $0.5 \%$ 用いた配 合についても検討する。供試体寸法は $400 \mathrm{~mm} \times 100 \mathrm{~mm} \times 100 \mathrm{~mm}$ とし, 型枠に打設, 表面を整形後, $20 \pm 2{ }^{\circ} \mathrm{C}$ 恒温室で 1 日養生し, 脱型後, $20 \pm 2{ }^{\circ} \mathrm{C}$ 水中で 7 日間の養生を行う。養生後, 上下面 $(100 \mathrm{~mm} \times 100 \mathrm{~mm})$ にエポキシ樹脂系接着剂を施し, 側面以外か らの水の蒸発を抑える。Table 8 に供試体名, 配合および体積表 面積比等の試験条件を示す。体積表面積比が乾燥収縮に及ぼす影 響を検討するため, 細骨材割合 $44 \%$ の配合のみ体積表面積比の 基準值とする $25 \mathrm{~mm}$ の供試体以外に, 側面 2 面に乾燥を妨げる ためにアルミテープを貼った供試体 (体積表面積比 $50 \mathrm{~mm}$ ) と側 面 3 面にアルミテープを貼った供試体 ( 体積表面積比 $100 \mathrm{~mm}$ ) を 準備し, 試験を行う。供試体本数は各 3 本とし, 基準とする細骨 材割合 $44 \%$, 体積表面積比 $25 \mathrm{~mm}$ の供試体のみ 2 回打設し, そ れぞれの打設時に 3 本，計 6 本作製する。

Fig. 8 に乾燥収縮試験の外観を示す。乾燥収縮試験は, モルタ ルおよびコンクリートの長さ変化試験方法 - 第 3 部 : ダイヤル ゲージ方法 (JIS A 1129-3) に準じて行う。供試体上面 (100 mm× $100 \mathrm{~mm})$ の中心にダイヤルゲージを設置し, 長さ $400 \mathrm{~mm}$ を基長

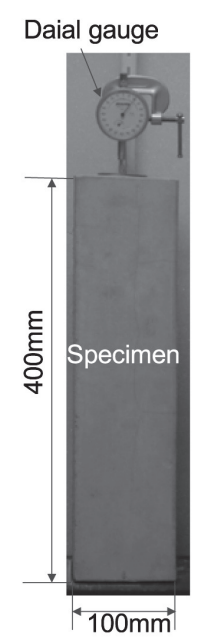

Fig.8 Condition of drying shrinkage test.

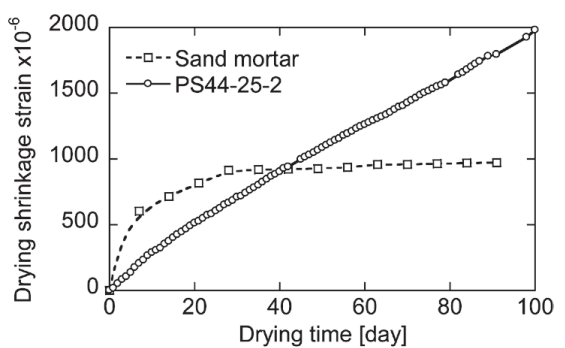

Fig.9 Comparison of drying shrinkage between PS mortar and sand mortar

とし, 収縮量を求める。細骨材割合 $44 \%$, 体積表面積比 $25 \mathrm{~mm}$ の供試体の 1 本は埋込型ひずみ計を用いて計測する。試験は平均 湿度 $40 \%$ ，温度 $20 \pm 1{ }^{\circ} \mathrm{C}$ に制御した恒温室で実施する。

\section{$4 \cdot 2$ 実験結果および考察}

細骨材の種類が乾燥収縮に及ぼす影響を検討するため, 細骨材 に川砂 (密度 $2.59 \mathrm{~g} / \mathrm{cm}^{3}$ ) を用いたモルタル (普通モルタル) と, 細骨材割合 $44 \%$, 体積表面積比 $25 \mathrm{~mm}$ の PS モルタル (PS44-25) の乾燥収縮量の比較を行う。Fig. 9 に普通モルタルと PS モルタ ルの乾燥収縮ひずみの経時変化を示す。乾燥材齢 91 日ではPS モルタルの乾燥収縮ひずみは普通モルタルの乾燥収縮ひずみの 2 倍程度である。また, 普通モルタルは乾燥材齢 28 日で乾燥収縮 が概柇収束しているのに対し，PS モルタルの乾燥収縮ひずみは 乾燥材齢 91 日でも増加傾向にあることが確認された。乾燥材齢 28 日までは, 普通モルタルの乾燥収縮ひずみは PS モルタルの乾 燥収縮ひずみより多く, 乾燥収縮の進行速度が速いことがわかる。 乾燥材齢 42 日以降においては, 同乾燥材齢時における乾燥収縮 ひずみの差が乾燥時間の経過に伴い増加する傾向が得られた。川 砂と PS 灰造粒骨材の違いは, 骨材の吸水率や密度などであり, それらがモルタルの乾燥収縮ひずみ, 収縮速度に影響を及ぼして いると考えられる。

Fig. 10 に乾燥材齢 400 日程度までの PS モルタルの乾燥収縮ひ ずみの経時変化を示す。全体的に PS モルタルは乾燥材齢 180 日 程度で進行速度が緩やかとなるが, 乾燥材齢 400 日においても乾 燥収縮ひずみは収束しておらず，増加の傾向がみられる。体積表 面積比の影響については体積表面積比が小さいほど傾きが大き く, 乾燥材齢 400 日で PS44-25 の乾燥収縮ひずみは PS44-100 の 乾燥収縮ひずみの約 1.6 倍となっている。細骨材割合の影響につ いては細骨材割合が大きいほど, 傾きも大きく収縮の進行速度が 速い傾向が得られた。同材齢時における乾燥収縮ひずみの差は, 

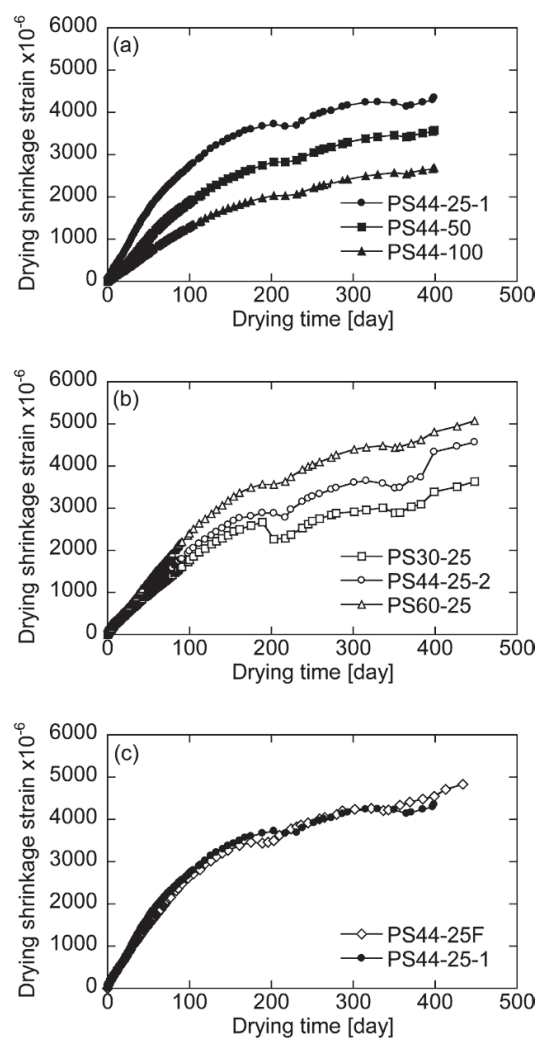

Fig.10 Change of drying shrinkage strain with time. (a): influence of volume/ surface ratio. (b): influence of percentage of PS to fine aggregate by mortar volume. (c): influence of fiber.

時間の経過に伴い大きくなっており，乾燥材齢 400 日で PS30-25 と PS60-25 の乾燥収縮ひずみには, 約 $1400 \times 10^{-6}$ の差が生じて いる。また，乾燥収縮ひずみの抑制効果を期待して PP 瀻維を混 入したが, 繊維を混入していない場合と乾燥収縮量はほぼ等しく, 繊維の乾燥収縮抑制効果は確認できなかった。

\section{$4 \cdot 3$ 既存の予測式による乾燥収縮の検討}

種々の配合において乾燥収縮ひずみを把握するために乾燥収縮 試験を実施することは，収縮の収束が長期間にわたる PS モルタ ルでは時間的に困難である場合が多いと考えられる。通常のコン クリートにおいては乾燥収縮試験の代わりとして予測式による収 縮量の把握方法があり, これまでにいくつかの乾燥収縮ひずみの 予測式が提案されている ${ }^{6-10)}$ 。本研究で想定しているプレキャス 卜部材においても設計との寸法の差異や変形など製品の品質管理 の上で, 収縮特性を把握・予測しておく必要があると考えられる。 これまでのPS コンクリートの検討で乾燥収縮量は通常の骨材を 用いたコンクリートの $1.4 \sim 1.7$ 倍になることがわかっているため, 性能評価をする上で重要な因子である ${ }^{3)}$ 。そこで, 既存のコンク リート乾燥収縮ひずみの予測式を用いて, PS モルタルの乾燥収縮 ひずみを求め, 計測值との比較を行い, 妥当性を評価する。

ここで用いる既存の予測式は, 土木学会式 ${ }^{6)}$, 建築学会式 ${ }^{7)}$, Gardner 式 ${ }^{8)}$ の 3 種類である。PS 灰造粒骨材は吸水率が高く, 単 位水量に影響を及ぼすと考えられ, 土木学会式, 建築学会式は, 予測する際に単位水量をパラメータで使用している。Gardner 式 は, 土木学会式, 建築学会式では使用されていないコンクリート 自体の特性に関するパラメータとして, 材齢 28 日の圧縮強さが 使用されている。これらの特徵に着目し, 本研究ではこれら 3 式 を検討の対象とする。ただし，これらの予測式はコンクリートの 乾燥収縮を予測するもので, モルタルは適用範囲外とも考えられ
る。また, 本研究では通常の骨材とは大幅に性質の異なる PS 灰 造粒骨材を用いているが，影響因子として骨材種類を挙げている 予測式は建築学会式のみである。建築学会式においても通常骨材 と軽量骨材のパラメータ值に差はなく，したがって既往の予測式 は適用できないことが予想される。しかしながら，これまでにな い全く新しい予測式を提案するのには膨大な実験データを必要と することなどから, 既往の予測式を参考に PS モルタルの実測值 に合う提案式を検討することとする。

土木学会式 ${ }^{6)}$ は, 次式で表される。

$$
\begin{aligned}
& \varepsilon_{s h}\left(t, t_{0}\right)=\frac{1}{10}\left[1-\exp \left\{-0.108\left(t-t_{0}\right)^{0.56}\right\}\right] \times \varepsilon_{s h \infty} \\
& \varepsilon_{s h \infty}=-50+78[1-\exp (h / 100)]+38 \log _{e} W-5\left[\log _{e}\left(\frac{V / S}{10}\right)\right]^{2}
\end{aligned}
$$

ここに, $\varepsilon_{s h}\left(t, t_{0}\right)$ : 乾燥材齢時における乾燥収縮ひずみ $\left(\times 10^{-6}\right)$, $\varepsilon_{s h \infty}$ : 乾燥収縮ひずみの最終值 $\left(\times 10^{-6}\right), h$ : 相対湿度 [\%], $W$ : 単位水量 $\left[\mathrm{kg} / \mathrm{m}^{3}\right],: V / S$ 体積表面積比 [mm], $t_{0}$ : 乾燥開始材齢 [ 日 ], $t$ : 乾燥材齢 [日 ] である。このとき, $t_{0}$ および $t$ に関しては, 式 (4) を用いて補正する。

$$
t_{0} \text { および } t=\sum_{i=1}^{n} \Delta t_{i} \times \exp \left[13.65-\frac{4000}{273+T\left(\Delta t_{i}\right) / T_{0}}\right]
$$

ここに, $\Delta t_{i}$ : 温度が $T\left[{ }^{\circ} \mathrm{C}\right]$ である日数， $T_{0}: 1^{\circ} \mathrm{C}$ である。 建築学会式 ${ }^{7)}$ は, 次式で表される。

$$
\begin{aligned}
& \varepsilon_{s h}\left(t, t_{0}\right)=\left[\frac{\left(t-t_{0}\right)}{0.16(V / S)^{1.8}+\left(t-t_{0}\right)}\right]^{0.8} \times \varepsilon_{s h \infty} \\
& \varepsilon_{s h \infty}=K_{1} \times t_{0}^{-0.08} \times\left[1-\left(\frac{h}{100}\right)^{3}\right] \ldots \ldots \ldots \ldots \ldots . . .
\end{aligned}
$$

$K_{1}=(11 \mathrm{~W}-1.0 C-0.28 G+404) \times \gamma_{1} \times \gamma_{2} \times \gamma_{3}$

ここに, $C$ : 単位セメント量 $\left[\mathrm{kg} / \mathrm{m}^{3}\right], G$ : 単位粗骨材量 $\left[\mathrm{kg} / \mathrm{m}^{3}\right]$, $\gamma_{1}, \gamma_{2}, \gamma_{3}$ : それぞれ骨材の種類, セメントの種類, 混和材の種 類の影響に関する係数である。

Gardner 式 ${ }^{8)}$ は, 次式で表される。

$\varepsilon_{s h}\left(t, t_{0}\right)=\beta(h) \times \beta(t) \times \varepsilon_{s h \infty}$

$\beta(h)=\left(1-1.18 h^{4}\right)$

$\beta(t)=\left[\frac{7.72+\ln \left(t-t_{0}\right)}{17.18}\right] \times\left[\frac{\left(t-t_{0}\right)}{\left(t-t_{0}\right)+0.015(V / S)^{2}}\right]$

$\varepsilon_{s h \infty}=900 \times K_{2} \times\left(\frac{f_{c m 28}}{f_{c m t c}}\right)^{1 / 2} \times\left(\frac{25}{f_{c m 28}}\right)^{1 / 2}$

$f_{c m t o}=f_{c m 28} \frac{t_{0}^{3 / 4}}{a+b t_{0}^{3 / 4}}$

ここに, $f_{c m 28}$ : 材齢 28 日の圧縮強さ [MPa], $f_{c m o}$ : 乾燥開始時の 圧縮強さ $[\mathrm{MPa}], K_{2}, a, b$ : セメントの種類の影響に関する係数 である。

土木学会式, 建築学会式, Gardner 式における乾燥収縮ひずみ 
Table 9 Predicted maximum drying shrinkage strain of PS mortar.

\begin{tabular}{lrrr}
\hline \multirow{2}{*}{ Specimen } & \multicolumn{3}{c}{ Maximum drying shrinkage strain $\times 10^{-6}\left(\mathrm{R}^{2}\right)$} \\
\cline { 2 - 4 } & \multicolumn{1}{c}{$\mathrm{JSCE}^{6)}$} & AIJ $^{7)}$ & Gardner $^{8)}$ \\
\hline Sand mortar & $912(0.96)$ & $1534(0.96)$ & $759(-)$ \\
PS44-25 & $1214(0.09)$ & $2223(0.57)$ & $937(-)$ \\
PS44-50 & $1127(0.12)$ & $2223(0.23)$ & $937(-)$ \\
PS44-100 & $991(0.15)$ & $2223(0.70)$ & $937(-)$ \\
PS30-25 & $1308(0.18)$ & $2754(0.71)$ & $888(-)$ \\
PS60-25 & $1068(0.44)$ & $1618(0.02)$ & $1067(-)$ \\
PS44-25F & $1214(0.09)$ & $2223(0.57)$ & $909(-)$ \\
\hline JSCE: Equation of Japan Society of Civil Engineers & \\
AIJ: Equation of Architectural Institute of Japan &
\end{tabular}
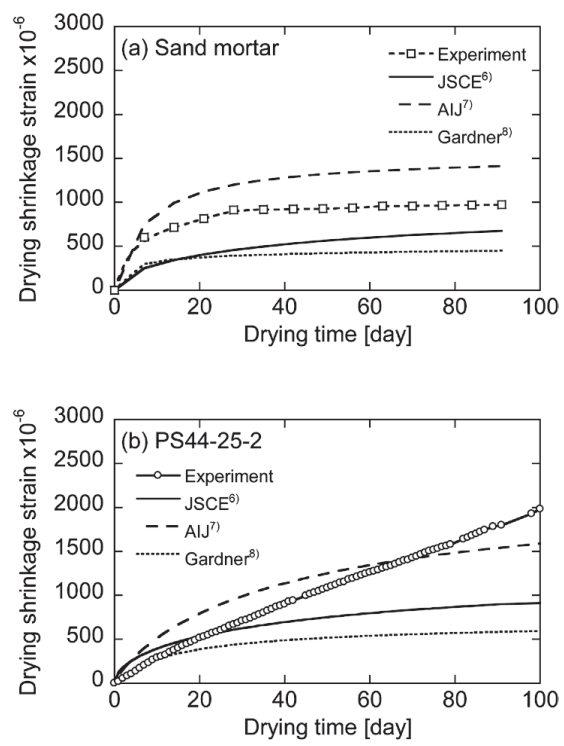

Fig.11 Comparisons of drying shrinkage strain with time between predictions and test measurements. JSCE and AIJ represent equation of Japan Society of Civil Engineers ${ }^{6)}$ and Architectural Institute of Japan ${ }^{7)}$, respectively.

の最終值は，それぞれ，式 (3)，式 (6) および式 (11) を用いて評 価できる。Gardner 式で用いる材齢 28 日の圧縮強さは，一軸圧縮 試験によって求める。一軸圧縮試験は，各配合において $\phi 50 \mathrm{~mm}$ $\times 100 \mathrm{~mm}$ の供試体を 5 本作製する。打設後 28 日間, $20 \pm 2{ }^{\circ} \mathrm{C}$ の 水中で養生後, 試験を行う。

Table 9 にこれら 3 式を用いて算出した乾燥収縮ひずみの最終 值を示す。また，予測值と計測值との相関関係の評価として決定 係数を示す。乾燥収縮ひずみの最終值は普通モルタルを除き計測 值を大幅に下回っている。また, 普通モルタルの決定係数は高く, 相関性が得られている。PS モルタルの決定係数は建築学会式の 予測值が最も高く, $0.6 〜 0.7$ を示している配合もあるが，一部 の配合で相関性が得られていない。土木学会式では全般的に相関 性が低く, Gardner 式では決定係数が著しく小さかったため表し ていない。Fig. 11 に各式を用いて評価した普通モルタルと PS モ ルタル (PS44-25) の予測值と計測值の経時変化を示す。普通モル タルの予測值と計測值を比較すると, 最終ひずみには差があるが, その増加傾向については定性的に一致する傾向が得られている。 一方，PS モルタルでは，定性的にも計測值を再現できていない。 PS モルタルの乾燥収縮の計測值は予測值と同様に乾燥収縮量の 時間増分が乾燥材齢とともに低下寸る傾向にあるが，収束時間が 遅いことが確認できる。Fig. 12 に 3 式の中で最も相関性の高い 建築学会式での予測值と計測值の相関関係を示す。乾燥収縮ひず みが大きい範囲では，全般的に過小評価していることがわかる。

以上のように, PS モルタルは普通モルタルと比較して乾燥収

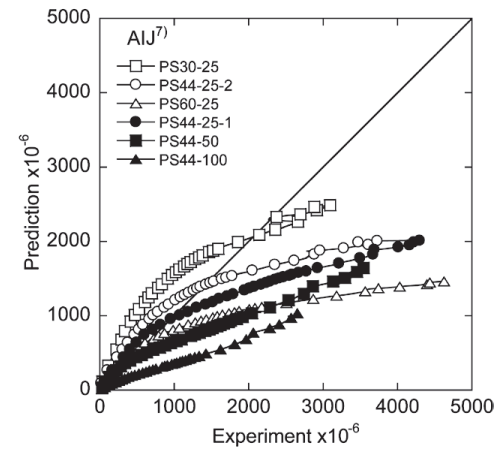

Fig.12 Comparison results of drying shrinkage strain between experiments and predictions by AIJ equation. AIJ represent equation of Architectural Institute of Japan ${ }^{7)}$.

縮ひずみの最終值が相対的に大きく，収縮が収束するまでにはよ り長い時間がかかるため，適用範囲が狭く，用途は限定される。 乾燥収縮抑制には膨張材や石灰石粗骨材が有効であるとの報告も されているが ${ }^{14)}$, これらの検討については今後の課題としたい。 また, 乾燥収縮ひずみの経時変化を既存のコンクリート用予測式 を用いて予測評価することは困難であり, PS モルタル独自の予 測式の検討が必要である。

\section{$4 \cdot 4$ PS モルタル用予測式の提案}

PS モルタル独自の乾燥収縮ひずみの予測式は, 土木学会式, 建 築学会式, Gardner 式を参考にして構築を試みる。式 (13) に示す ように, 乾燥収縮ひずみは 3 式とも収縮挙動を表す時間依存性の 項 $\alpha(t)$ に, 乾燥収縮ひずみの最終值 $\varepsilon_{s h \infty}$ を乗じる形で求められる。

$$
\varepsilon_{s h}\left(t, t_{0}\right)=\alpha(t) \times \varepsilon_{s h \infty}
$$

そこで，乾燥収縮ひずみの最終值と収縮挙動を表す時間依存性 の項それぞれ検討を行う。まず, 収縮挙動を表す時間依存性の項 では，土木学会式は，パラメータに乾燥時間が使用されており， 建築学会式, Gardner 式には，乾燥時間と体積表面積比が使用さ れている。前述の実験結果より体積表面積比が乾燥収縮量に影響 を及ぼすことがわかっており, また, 建築学会式の予測精度が 1 番高い結果であるため, 時間依存性の項は, 建築学会式を参考に する。つぎに, 各予測式の乾燥収縮ひずみの最終值では, 細骨材 割合の影響を受けるパラメータは, 単位水量, 単位セメント量, 材齢 28 日の圧縮強さと考えられるが，いずれの式にも，いずれ かのパラメータが含まれており, 有用性が示唆される。しかし, 計測值は細骨材割合が大きいほど乾燥収縮ひずみが大きくなる傾 向を示しており, Table 9 に示した各式の乾燥収縮ひずみの最終 值から判断すると Gardner 式のみが，計測值を定性的に再現でき ている。以上より, 乾燥収縮ひずみの最終值を予測評価する式は, Gardner 式を参考にする。

建築学会式および Gardner 式を組み合わせた複合式は次式のよ うに表される。

$$
\begin{aligned}
& \varepsilon_{s h}=\left[\frac{\left(t-t_{0}\right)}{m_{1}(V / S)^{m_{2}}+\left(t-t_{0}\right)}\right]^{m_{3}} \times \varepsilon_{s h \infty} \cdots \\
& \varepsilon_{s h \infty}=m_{4} \times K \times\left(\frac{f_{c m 28}}{f_{c m t_{0}}}\right)^{m_{5}} \times\left(\frac{25}{f_{c m 28}}\right)^{m_{6}}
\end{aligned}
$$

ここに, $m_{1} \sim m_{6}:$ 定数である。

さらに, 計測の結果から, $m_{3}$ および $m_{4}$ は体積表面積比に影響 されていることから体積表面積比の関数で表すこととし, 最小二乗 法により回帰分析を行い, 各定数を同定すると次式の通りとなる。 

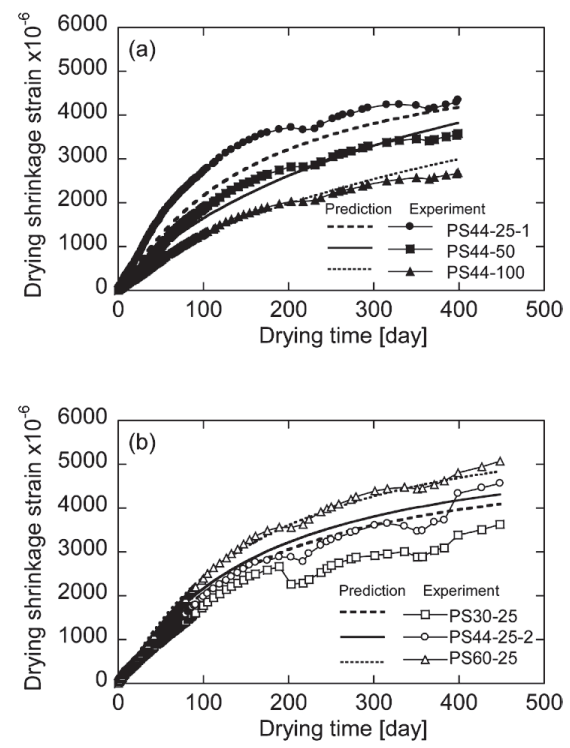

Fig.13 Change of drying shrinkage strain with time predicted by proposed equation. (a): influence of volume/surface ratio. (b): influence of percentage of PS to fine aggregate by mortar volume.
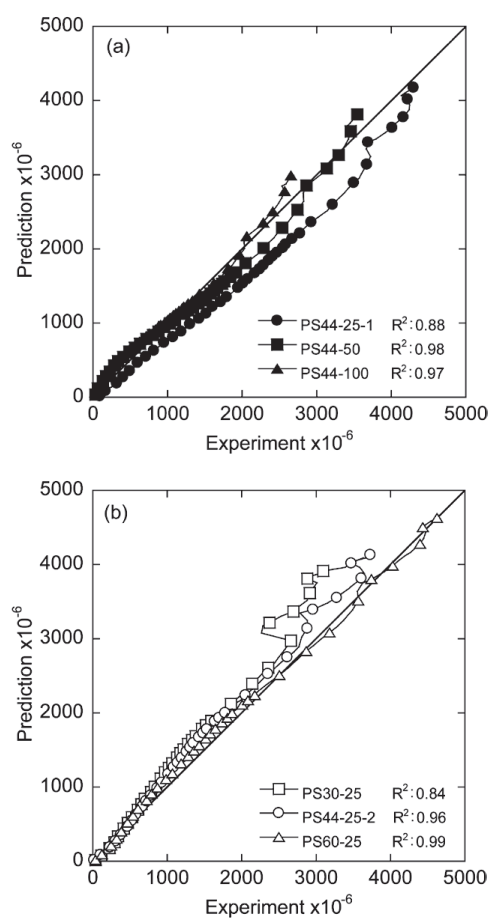

Fig.14 Comparison results of drying shrinkage strain between experiments and prediction evaluated from proposed equation. (a): influence of volume/ surface ratio. (b): influence of percentage of PS to fine aggregate by mortar volume.

$$
\begin{aligned}
& \varepsilon_{s h}=\left[\frac{\left(t-t_{0}\right)}{0.2(V / S)^{2.0}+\left(t-t_{0}\right)}\right]^{[0.5+18 /(V / S)]} \times \varepsilon_{s h \infty} \cdots \ldots \ldots \ldots . . . \\
& \varepsilon_{s h \infty}=5800 \times\left[\frac{(V / S)}{25}\right]^{0.4} \times K \times\left(\frac{f_{c m 28}}{f_{c m t_{0}}}\right)^{0.4} \times\left(\frac{25}{f_{c m 28}}\right)^{0.5} \cdots
\end{aligned}
$$

Fig. 13 に提案式よる乾燥収縮ひずみの予測值と計測值を示し, Fig. 14 に相関関係を示す。また, 眓中に予測值と計測值との相 関関係の評価として決定係数を示す。提案式を用いた予測值は,
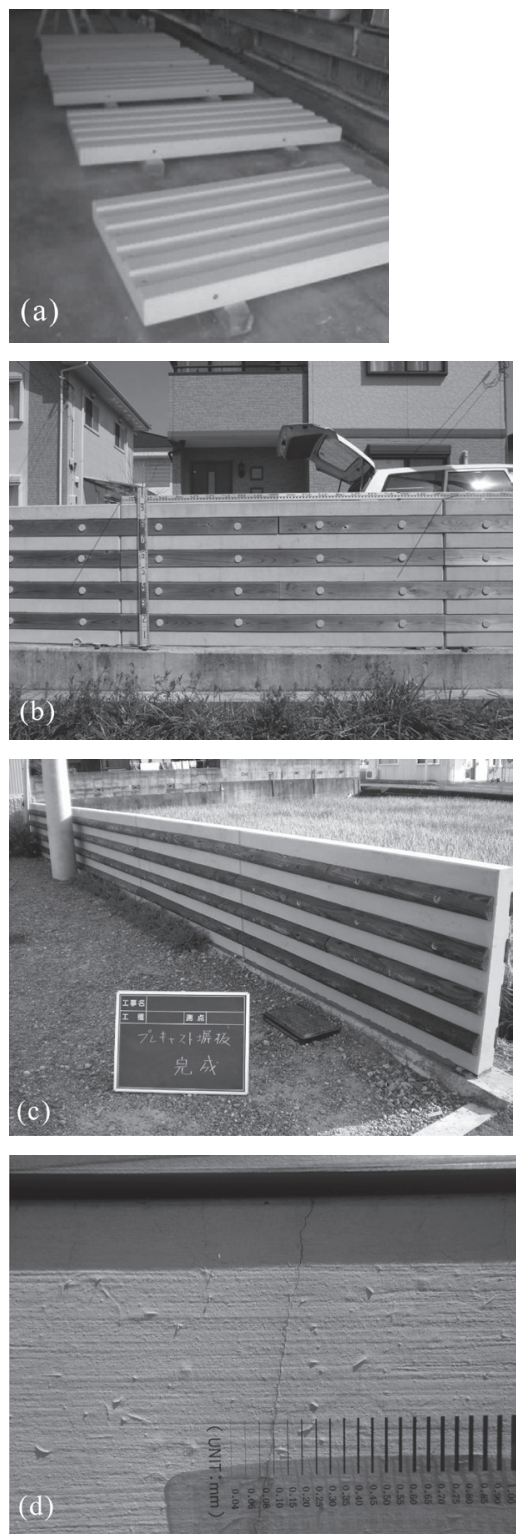

Fig.15 Conditions of precast panel of PS mortar used for wall. (a): PS mortar panel in a factory. (b): panel size: $0.9 \mathrm{~m} \times 1.0 \mathrm{~m} \times 0.1 \mathrm{~m}$. (c): whole view of the wall. (d): crack occurred on a panel.

体積表面積比および細骨材割合の乾燥収縮への影響を反映し計測 值を精度良く再現していることが確認できる。建築学会式および Gardner 式を組み合わせた複合式にて PS モルタルの乾燥収縮は 予測可能であるといえる。

\section{PS 灰造粒骨材を用いたモルタルの実用性の検討}

プレキャスト材としてのPS モルタルの実用性について検討す るために, ここでは, PS モルタルにてプレキャスト塀板を作製し, 一般住宅地の塀として試験施工し, 経過観察する。

Fig. 15 にプレキャスト塀板製品, 施工状況, 経過観察結果を示 す。プレキャスト塀板はコンクリート二次製品を取り扱う製造工 場にて作製し，一定期間養生を行った。配合は Table 4 で示した 水セメント比 $30 \%$, 細骨材の混入割合は容積比で全体積の $37 \%$, 混入する繊維はポリプロピレン繊維とし全体積に対して $0.2 \%$ 添 加する。塀板 1 枚の寸法は $2000 \mathrm{~mm} \times 900 \mathrm{~mm} \times 120 \mathrm{~mm}$ である。 これを愛媛県四国中央市の一般住宅地の塀として長さ $9.6 \mathrm{~m}$ に渡 り施工した。美観のため塀板の表面には間伐材で作製した木質材 
料を施している。施工完了後, 変色, 変形, ひび割れ等の劣化状 況を目視にて経過観察した結果，施工後 30 力月において著しい 変色や変形などは観察されなかった。乾燥収縮量が大きく発生が 懸念されるひび割れについては, 施工後 2 カ月から表面に微細な ひび割れが発生し, 約 12 カ月後まで増加がみられ，その後はひ び割れ幅の拡大や本数の増加はみられていない。ひび割れ幅は $0.04 \sim 0.10 \mathrm{~mm}$ であり, 垂直方向に発生し, 間隔は $5 \sim 10$ 数 $\mathrm{cm}$ である。一方, 同時に同配合で作製した $1000 \mathrm{~mm} \times 1000 \mathrm{~mm} \times 20 \mathrm{~mm}$ のPS モルタル平板を, 乾燥収縮ひず夕測定と同条件の平均湿度 $40 \%$ ，温度 $20 \pm 1{ }^{\circ} \mathrm{C}$ 制御した恒温室に設置し，経過観察を行っ たが，ひび割れは発生していない。また，前述の乾燥収縮ひずみ を測定した供試体にもひび割れが発生した事例がみられた。PS モルタルは高い吸水性を有していることから，モルタル表面と内 部の乾燥速度の違いにより, 表面と内部の収縮量に差が生じ, ひ び割れの原因になっているものと推察でき, PS モルタルの厚み が影響していると考えられる。PS モルタルは乾燥収縮ひずみが 大きく, ひび割れの可能性も高いことから使用範囲は限定的であ ると考えられる。適用にあたっては使用環境, 耐久性, 美観等を 考慮することが必要である。

\section{6. ま と め}

製紙工場から排出される産業廃棄物の製紙スラッジ焼却灰の有 効利用の観点から, フライアッシュと混合し, 固化材にセメント を用いた造粒材料を作製し，セメントモルタルの細骨材として使 用した場合の適用性について，主にプレキャスト材に使用するこ とを念頭に検討を行った。具体的には埋設型モルタル製型枠への PS モルタルの適用性について, 流動性, 強度および型枠として 使用した際の内部コンクリートへの養生効果について評価した。 つぎに，乾燥収縮試験を実施することにより，PS モルタルの乾 燥収縮挙動を評価し, また, 乾燥収縮挙動を再現できる予測式を 提案し, その有用性について検討した。さらに, PS モルタルの 実用性について検討するために，プレキャス卜塀板を作製し，一 般住宅地の塀として試験施工し, 経過観察した。本研究で得られ た結果を要約すると以下の通りである。

(1)PS モルタル平板を型枠として用いて養生したコンクリートは 強度, 密実性が高く, PS モルタルのプレキャスト型枠として の有効性が確認された。

(2)PS モルタルの乾燥収縮ひずみは，乾燥材齢 400 日で約 2000

〜 $5000 \times 10^{-6}$ となり, 普通モルタルと比べて非常に大きく, PS 灰造粒骨材の吸水率や密度が乾燥収縮に影響を及ぼしてい
ると推察される。また, 体積表面積比が大きいほど乾燥収縮 ひずみは小さく, 細骨材割合が小さいほど乾燥収縮ひずみは 小さいことが確認された。繊維混入による乾燥収縮量の抑制 効果は確認できなかった。乾燥収縮量については上限值が規 定されている場合もあることから，用途は限定されると考え られる。

(3)既存のコンクリートの乾燥収縮ひずみの予測式で PS モルタル の乾燥収縮ひずみを評価した結果，予測式を用いた計測值の 再現精度は低く，予測評価することは困難であることがわかっ た。そのため，新たな PS モルタルの乾燥収縮ひずみ予測式を 提案した。提案式と計測值の相関は比較的高く, 乾燥収縮を 予測可能である。

(4)プレキャスト塀板を用いた実用性検討において，塀板に 0.04 〜 $0.10 \mathrm{~mm}$ 程度のひび割れの発生が観察された。PS モルタル の適用にあたっては使用環境，耐久性，美観等を考慮するこ とが必要である。

(5)本研究ではプレキャスト材料の中でも埋設型モルタル製型枠 および塀板について検討した。要求される性能としてはフレッ シュ時の流動性, 硬化後の強度 (特に曲げ強さ) であると考え られ，それそれ目標值を設定したが，それらを満足する配合 が得られた。また，型枠では養生効果が認められ，塀板では ひび割れや劣化などを観察し，実用に耐え得ることを示した。 ただし，PS モルタルは通常のモルタルと比較し，乾燥収縮量 が大きく収束も遅いことから, 設計段階から収縮量を予測す るなどの対策が必要であると考えられる。

\section{References}

1) Ehime prefecture: Ehime eco-town plan, (2006), pp. 19-20

2) T. Matsuo, N. Kinoshita, T. Kawaguchi and I. Ujike: Summaries of 14th Annual Meeting of JSCE, Shikoku branch (2008), pp. 276-277.

3) N. Kinoshita, T. Kawaguchi, T. Matsuo and H. Yasuhara: Journal of MMIJ, 128 (2012), 576583.

4) O. Kayali, M. N. Haque, B. Zhu: Cement and Concrete Research, 29 (1999), 1835-1840.

5) K. Imamoto, S. Ishii and M. Arai: J. Struct. Const. Eng., AIJ, 606 (2006), 9-14.

6) JSCE: Standard specification for concrete structures -2007, design, (2007), pp. 45-46.

7) Y. Sato, C. Kiyohara, K. Teranishi, K. Imamoto, H. Mihashi, and H. Okada: J. Struct. Const. Eng., AIJ, 597 (2005), 9-15.

8) N.J.Gardner : Desing Provisions for Shrinkage and Creep of Concrete, ACI SP194-3 (2000), pp. 101-133.

9) Z. P. Bazant and W. P. Murphy: Material and Structures, 28 (1995), 357-365

10) K. Teranishi and Y. Sato: J. Struct. Const. Eng., AIJ, 602 (2006), 21-28.

11) ISRM: Int. J. Rock Mech. Min. Sci, 22 (1985), 51-60.

12) S. Kohno and I. Ujike: Proc. Japan Concrete Institute, (JCI, Tokyo, 1999), pp. 847-852.

13) Japan Crushed Stone Association: Proc. MMIJ Fall Meeting (2011), Vol. A, pp. 97-104.

14) S. Fukushima, C. Hashimoto, N. Heng and T. Watanabe: Proc. Japan Concrete Inst., 29 (2007), pp. 645-650 